\title{
夜間高校定時制生徒の有酸素的作業能に関する研究
}

\author{
石崎忠 利* 吉沢茂 弘**

\section{THE STUDIES ON AEROBIC WORK CAPACITIES OF THE NIGHT PART-TIME HIGH SCHOOL STUDENTS}

\author{
Tadatoshi Ishizaki and Shigehiro Yoshizawa
}

According to the past results of Sports Test, it was found that the night part-time high school students showed the significantly lower performance in endurance run than the full-time high school students. This fact may be partly due to the fatigue and the lack of motives necessarily caused by their mental and physical works in day time. This study was attempted to determine their aerobic work capacities $\left(\mathrm{PWC}_{170}, \dot{\mathrm{V}}_{\mathrm{o}_{2}} \mathrm{max}\right)$ in the same experimental condition as used for the full-time high school students and simulteneously comparing them with those of the full-time high school students in the same district. The subjects were 59 male and 38 female, aged from 15 to 19 years.

The results obtained in this study were as follows:

1) The mean values of $\mathrm{PWC}_{170}(\mathrm{kpm} / \mathrm{min})$ for boys increased slightly with increasing ages till 18 years. But girls showed almost same values through the ages. The maximal value were $910 \mathrm{kpm} / \mathrm{min}$ at the age of 18 years for the boys and $617 \mathrm{kpm} / \mathrm{min}$ for the girls aged 16 years respectively.

2) For boys the mean values of $\mathrm{PWC}_{170}(\mathrm{kpm} / \mathrm{kg} / \mathrm{min})$ ranged from 14 to $15 \mathrm{kpm} /$ $\mathrm{kg} / \mathrm{min}$ and ranged from 10 to $11 \mathrm{kpm} / \mathrm{kg} / \mathrm{min}$ for girls.

3) As for the mean values of $\dot{\mathrm{V}}_{2} \max (l / \mathrm{min})$ of the boys increased slightly untill the age of 18 years. But girls were same in values through all the ages. The maximal values were $2.71 / \mathrm{min}$ at the 18 years for boys and $1.81 / \mathrm{min}$ for girls aged 15 years respectively.

4) For boys the mean values of $\dot{\mathrm{V}}_{2} \max (\mathrm{ml} / \mathrm{kg} / \mathrm{min})$ decreased slightly from 49.48 $\mathrm{ml} / \mathrm{kg} / \mathrm{min}$ with ages. The mean values of $\dot{\mathrm{Vo}_{2}} \max (\mathrm{ml} / \mathrm{kg} / \mathrm{min})$ ranged from 34 to 35 $\mathrm{ml} / \mathrm{kg} / \mathrm{min}$ for girls.

5) The night part-time high school students were lower than the full-time high school students in $\mathrm{PWC}_{170}(\mathrm{kpm} / \mathrm{min}), \mathrm{PWC}_{170}(\mathrm{kpm} / \mathrm{kg} / \mathrm{min}), \dot{\mathrm{V}} \mathrm{o}_{2} \mathrm{max}(1 / \mathrm{min})$ and $\dot{\mathrm{V}} \mathrm{o}_{2} \max$ $(\mathrm{ml} / \mathrm{kg} / \mathrm{min})$ for boys. For girls no significant differences were in these valiables after the age of 16 years.

(J. Physical Fitness Japan 1976, $25: 129 \sim 138$ )

\section{は じめに}

夜間高校定時制生徒に関する体育学的研聟は, これまで次の 5 つの角度から行なわれてきたよう に思われる。すなわち, (1)体力面では, 元ら ${ }^{28) 29)}$, 大越 ${ }^{30)}$, 増田 $ら^{24)}$, 条野 ${ }^{20)}$, 加藤 ${ }^{16)}$, (2)栄菁面 からは, 藤本ら ${ }^{6)}$, 鈴木ら ${ }^{32)}$, (3) 疲学調烃では, 我妻 ${ }^{37) 38)}$, 前田 ${ }^{23)}$, 井沺 $ら^{7)}$, 畄葉 ${ }^{12)}$, (4) 健康 管理面では, 近藤ら ${ }^{18)}$, 高橋 ${ }^{33) 34)}$, 小谷ら ${ }^{19)}$,
そして (5) 生活时間調査として, 千葉ら ${ }^{4) 51}$, 増田 ら 25) と多くの研究者によって，それぞれの観点か ら検討が加えられている。しかし，(1)の体力面に 関する研究は比較的少なく，とりわけ体力のなか でもその中核となっている有酸素的作業能につい ての研究はわが国ではまた行なわれていない。

これまで，ヒトの有酸素的作業能を测定評価す るために国際的には広く2つの方法が用いられて きた。その 1 つは作業成績 (Performance) であ
* 宇都宮大学教養部

** 宇都宮大学教育学部
Faculty of General Education, University of Utsunomiya

Faculty of Education, University of Utsunomiya 
り，第 2 は身体資源 (Physical resources) からみ たものである。そこで，まず Performance の立 場からスポーツテストの持久走の成績より夜間高 校定時制生徒と全日制生徒を比較すると，男女と あすへてての年令に执いて全日制生徒が明らかにす ぐれていることが，杤木県における過去 8 年間の 成績及び全国の過去 8 年間の成績において認めら れた ${ }^{27) 36) 。 ~}$

このように Performance の面からみると, 夜間 高校定时制生徒は全日制生徒より少っていると言 えるが，四在の液開高校定時制生徒に対する测定 環境及び测定条件というものを考虑すると, Performance だけで結論づけるのは早計であるよう に思われる。なぜならば, 伩間高校定時制坐徒は 1 日の勤務で身心共に疲労し，その疲労した状態 で測定を受けていると思われるからである。した がって，十分な意欲をもってテストに参加してい るか, あるいは個人の取大限の能力が発揮されて いるのかというようなことが問題になってくるか らである。
本研究はこうした意味から夜間高枍定時制生徒 について, 労㗢と学業との二重の生活構造からく る疲労ということを十分に考虑し，できるだけ疲 労の风子を除き全日制生徒と测定条件を同じくす るよう配慮しつつ, Physical resources の立場か ら，持久性の背景にある有酸素的作業能について 測定し，その実態を明らかにし，あわせて，同年 代でしかも同一の測定方法によって嘛木県下で吉 沢 ${ }^{41)}$ にって得られた全日制生徒の資料と比較検 討を試みようとしたものである。

\section{研 究 方 法}

\section{1. 被検者及ひ測定期間}

被検者は杤小徂站氏家高等学校の依間高校定侍 制生徒97名（男子59名，女子38名）を対象に行な った。なお，被検者の身体的特徵は第 1 表に示し た通りである。测定期間は佃和 47 年 10 月から明和 49年11月までの日㫿日，祭日を利用した。すなわ ち、できるだけ全日制生徒と测定条件を同じく し, 尽間の労働による疲労の因子を除くために仕

Table 1 Physical characteristics of subjects

\begin{tabular}{|c|c|c|c|c|c|c|c|c|c|c|c|}
\hline \multirow{2}{*}{\multicolumn{2}{|c|}{$\begin{array}{l}\text { Age (years) } \\
\text { Sex }\end{array}$}} & \multicolumn{2}{|c|}{15} & \multicolumn{2}{|c|}{16} & \multicolumn{2}{|c|}{17} & \multicolumn{2}{|c|}{18} & \multicolumn{2}{|c|}{19} \\
\hline & & $\mathrm{M}$ & $\mathrm{F}$ & $\mathrm{M}$ & $\mathrm{F}$ & $\mathrm{M}$ & $\mathrm{F}$ & $\mathrm{M}$ & $\mathrm{F}$ & $\mathrm{M}$ & $\mathrm{F}$ \\
\hline \multicolumn{2}{|c|}{ Nr. of subj. } & 9 & 6 & 18 & 8 & 13 & 12 & 10 & 6 & 9 & 6 \\
\hline \multicolumn{2}{|c|}{ Body height $(\mathrm{cm})$} & $\begin{array}{r}159.2 \\
(4.8)\end{array}$ & $\begin{array}{r}153.8 \\
(4.0)\end{array}$ & $\begin{array}{r}162.8 \\
(4.5)\end{array}$ & $\begin{array}{r}155.3 \\
(4.5)\end{array}$ & $\begin{array}{r}165.9 \\
(6.3)\end{array}$ & $\begin{array}{c}152.3 \\
(3.5)\end{array}$ & $\begin{array}{c}166.3 \\
(6.1)\end{array}$ & $\begin{array}{c}152.9 \\
(3.9)\end{array}$ & $\begin{array}{r}169.0 \\
(6.0)\end{array}$ & $\begin{array}{c}152.5 \\
(8.6)\end{array}$ \\
\hline \multicolumn{2}{|c|}{ Body weight $(\mathrm{kg})$} & $\begin{array}{l}52.48 \\
(5.4)\end{array}$ & $\begin{array}{l}53.28 \\
(2.4)\end{array}$ & $\begin{array}{l}54.21 \\
(6.0)\end{array}$ & $\begin{array}{l}53.06 \\
(5.6)\end{array}$ & $\begin{array}{l}55.25 \\
(6.8)\end{array}$ & $\begin{array}{l}52.88 \\
(5.3)\end{array}$ & $\begin{array}{l}58.83 \\
(9.3)\end{array}$ & $\begin{array}{l}50.21 \\
(3.0)\end{array}$ & $\begin{array}{l}57.67 \\
(5.3)\end{array}$ & $\begin{array}{l}52.11 \\
(4.5)\end{array}$ \\
\hline \multicolumn{2}{|c|}{ Chest girth $(\mathrm{cm})$} & $\begin{array}{l}81.2 \\
(6.1)\end{array}$ & $\begin{array}{l}81.0 \\
(1.9)\end{array}$ & $\begin{array}{l}79.7 \\
(4.7)\end{array}$ & $\begin{array}{l}82.2 \\
(4.1)\end{array}$ & $\begin{array}{l}82.9 \\
(6.2)\end{array}$ & $\begin{array}{l}82.3 \\
(4.3)\end{array}$ & $\begin{array}{l}85.7 \\
(8.1)\end{array}$ & $\begin{array}{l}79.5 \\
(3.8)\end{array}$ & $\begin{array}{l}86.6 \\
(5.6)\end{array}$ & $\begin{array}{l}80.0 \\
(3.4)\end{array}$ \\
\hline \multicolumn{2}{|c|}{ Sitting height $(\mathrm{cm})$} & $\begin{array}{l}85.5 \\
(3.9)\end{array}$ & $\begin{array}{l}84.8 \\
(0.7)\end{array}$ & $\begin{array}{l}87.8 \\
(2.7)\end{array}$ & $\begin{array}{l}86.1 \\
(1.8)\end{array}$ & $\begin{array}{l}89.7 \\
(4.2)\end{array}$ & $\begin{array}{l}84.0 \\
(1.6)\end{array}$ & $\begin{array}{l}90.1 \\
(3.7)\end{array}$ & $\begin{array}{l}84.6 \\
(1.6)\end{array}$ & $\begin{array}{l}91.0 \\
(2.8)\end{array}$ & $\begin{array}{l}82.4 \\
(3.4)\end{array}$ \\
\hline \multirow{4}{*}{ 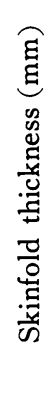 } & Upper arm & $\begin{array}{l}10.5 \\
(3.4)\end{array}$ & $\begin{array}{l}17.6 \\
(2.7)\end{array}$ & $\begin{array}{c}9.1 \\
(4.4)\end{array}$ & $\begin{array}{l}19.4 \\
(5.1)\end{array}$ & $\begin{array}{c}6.7 \\
(2.3)\end{array}$ & $\begin{array}{l}18.7 \\
(6.1)\end{array}$ & $\begin{array}{c}7.7 \\
(2.8)\end{array}$ & $\begin{array}{l}18.7 \\
(3.1)\end{array}$ & $\begin{array}{c}5.4 \\
(1.8)\end{array}$ & $\begin{array}{l}18.2 \\
(5.4)\end{array}$ \\
\hline & Scapula & $\begin{array}{l}10.4 \\
(2.9)\end{array}$ & $\begin{array}{l}16.7 \\
(2.1)\end{array}$ & $\begin{array}{c}9.7 \\
(3.7)\end{array}$ & $\begin{array}{l}19.3 \\
(6.2)\end{array}$ & $\begin{array}{c}8.9 \\
(2.4)\end{array}$ & $\begin{array}{l}18.8 \\
(5.3)\end{array}$ & $\begin{array}{c}9.7 \\
(2.4)\end{array}$ & $\begin{array}{l}15.8 \\
(3.2)\end{array}$ & $\begin{array}{c}8.5 \\
(2.4)\end{array}$ & $\begin{array}{l}19.0 \\
(4.7)\end{array}$ \\
\hline & Waist & $\begin{array}{l}14.6 \\
(8.1)\end{array}$ & $\begin{array}{l}21.6 \\
(4.8)\end{array}$ & $\begin{array}{c}9.9 \\
(5.9)\end{array}$ & $\begin{array}{l}21.8 \\
(5.0)\end{array}$ & $\begin{array}{l}10.1 \\
(3.3)\end{array}$ & $\begin{array}{l}22.2 \\
(7.1)\end{array}$ & $\begin{array}{l}12.0 \\
(5.0)\end{array}$ & $\begin{array}{l}20.0 \\
(2.5)\end{array}$ & $\begin{array}{l}11.0 \\
(3.2)\end{array}$ & $\begin{array}{l}20.6 \\
(3.9)\end{array}$ \\
\hline & Umbilicus & $\begin{array}{l}11.4 \\
(4.1)\end{array}$ & $\begin{array}{l}19.2 \\
(5.5)\end{array}$ & $\begin{array}{l}10.3 \\
(8.0)\end{array}$ & $\begin{array}{l}16.7 \\
(4.6)\end{array}$ & $\begin{array}{c}7.8 \\
(3.0)\end{array}$ & $\begin{array}{l}21.7 \\
(6.8)\end{array}$ & $\begin{array}{l}10.1 \\
(5.3)\end{array}$ & $\begin{array}{l}15.9 \\
(5.1)\end{array}$ & $\begin{array}{c}9.6 \\
(3.8)\end{array}$ & $\begin{array}{l}19.5 \\
(6.4)\end{array}$ \\
\hline
\end{tabular}


事のない日を選んで実験を遂行した。

\section{2. 測定項目とその測定方法}

(1) 体格

身長, 座高及び胸囲の測定にはマルチンの人体 計測器を用い，体重の測定には大和製衡の $0.5 \mathrm{~kg}$ 単位の $120 \mathrm{~kg}$ 秤量のバランスを用いた。

(2) 皮脂厚

栄研式皮脂厚計を用い，からだの右側で次の 4 点について測定した。

a. 上腕背部——肩峰之肘頭を絬ぶ線の中点

b. 啹甲骨下角部直下

c. 腸骨棱部——腋窩止中線と㑪の高さにおけ る立位水平線之の交点

d. 脐部——脐の右側約 $2 \mathrm{~cm}$

(3) $\mathrm{PWC}_{170}$ (Physical Working Capacity 170 : $\mathrm{PWC}_{170}$ )

モナーク社製自転車エルゴメーターにより Macnab, R.B.J. ${ }^{22)}$ に準じて回転数 50rpm, 4 分 間， 3 点法を採用し，横軸飞作業強度（kpm/ $\mathrm{min}$ ), 縦軸に心拍数 (beats $/ \mathrm{min}$ ) をとり，その 回㷌直線の方程式を求め, それから $\mathrm{PWC}_{170}$ の決 定を行なった。

(4) 最大酸素摄取量

最大酸素椇取量 (Maximal Oxygen Uptake : $\left.\dot{\mathrm{V}}_{\mathrm{O}_{2}} \max \right)$ の測定は, $\mathrm{PWC}_{170}$ の测定と同じように モナーク社製の自転車エルゴメーターを用い, IBP Hand book No.9 ${ }^{39)}$ に準じて漸増負荷法で行 ない, 呼気ガスは労研式大型ガス分析器で分析し た。心拍数は採気開始と同時に $\mathrm{V}_{4}$ 誘導により連 続的に記録し， $\dot{V} o_{2} \max$ 分析の対象になった呼気 採気時 1 分間の全心拍を最大努力時における有酸 素的作業能の心拍数とした。

ところで, $\dot{V}_{2} \max$ に関して比較検討を試みよ うとするたびに，いつも論議されているととに， はたして做人の $\dot{V} o_{2} \max$ がテストで発現されたか どうかという問題がある。そとで，その判定基準

(Creteria) の手掛りとして心拍数, R.Q につい てみると，まず心拍数は Balke, B. ${ }^{2}$ が 190 を上回 る時とし，次に R.Q についてみると，Binkhorst, R.A. ${ }^{3)}$ 及び Wilmore, J.H. ${ }^{40)}$ は R.Q が 1.00 を上 回る場合としている。そてで本研究の結果を第 2 表よりみると，心拍数についてはすべての年令の 男女において 190 を上回っており，また R.Q に
ついてあ 1.00 以上であった。さらには, Lester, M. ら ${ }^{21)}$ が述べているような，十分に追い込んだ 時点での呼吸困難及び顔面蒼白というような外観 的目安が観察された。乙うしてみると，本研労に おいての分析対象となった呼気ガスは $\dot{V} o_{2} \max に$ 到達しているものと判断できる。

\section{結果及び考察}

1. 夜間高校定時制生徒の有酸素的作業能につ いて

第 2 表は本研究で得られた15才から19才までの 液間高校定時制生徒の有酸素的作:業能を示したも のである。

$\mathrm{PWC}_{170}(\mathrm{kpm} / \mathrm{min})$ についてみると，男子は 18 才の $910 \mathrm{kpm} / \mathrm{min}$ までわずかではあるが増加 の傾向を示し，19才で咸少した。それに対し女子 は, 16 才で $617 \mathrm{kpm} / \mathrm{min}$ と最も高い值を示した が，全体的にみると $550 \sim 600 \mathrm{kpm} / \mathrm{min}$ とほぼ一 定水準を保っていた。女子の男子に対する比率を 性差としてみると，15才で70\%，16才で78\%，17

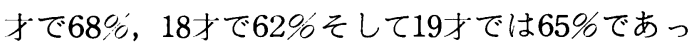
た。

$\dot{\mathrm{V}}_{\mathrm{o}_{2}} \max (l / \mathrm{min})$ については，男子が15才から 18才までわずかではあるが増加を示し，19才で橫 ばい状態になるというように， $\mathrm{PWC}_{170}(\mathrm{kpm} /$ min）とほぼ同じ傾向をたどっていた。全体的に は 2. 6 2.7 l/min の範囲にあった。他方，女子 は15才から19才まで $1.8 \mathrm{l} / \mathrm{min}$ 前後とほぼ一定の 水準を示した。性差については15才，16才，17才， 18才，19才で73\%，71\%，67\%，65\%，65\%と年 令の増加とともに大きくなることがわかった。

次に $\mathrm{PWC}_{170}(\mathrm{kpm} / \mathrm{kg} / \mathrm{min})$ てついてみると, 年令によってわずかの增減は認められるが，男子 では 14〜 $15 \mathrm{kpm} / \mathrm{kg} / \mathrm{min}$ ，女子では $10 \sim 11 \mathrm{kpm} /$ $\mathrm{kg} / \mathrm{min}$ と15才から19才までほぼ一定水準にあっ た。性差については，16才で $80 \%$ と少なかった が，その他の年令では約70\%であった。

$\dot{\mathrm{V}} \mathrm{o}_{2} \max (\mathrm{ml} / \mathrm{kg} / \mathrm{min})$ は, 男子が15才の 49.48 $\mathrm{ml} / \mathrm{kg} / \mathrm{min}$ をピークとして, その後 $47 \sim 48 \mathrm{ml} /$ $\mathrm{kg} / \mathrm{min}$ というようにわずかではあるが減少の傾 向がみられた。一方，女子においては 18 才で $36.35 \mathrm{ml} / \mathrm{kg} / \mathrm{min}$ と最も高い值を示したが，その 他の年令では 34〜 35 $\mathrm{ml} / \mathrm{kg} / \mathrm{min}$ の範囲にあり， 
Table 2 Aerobic work capacities of subjects

\begin{tabular}{|c|c|c|c|c|c|c|c|c|c|c|}
\hline Age (years) & \multicolumn{2}{|c|}{15} & \multicolumn{2}{|c|}{16} & \multicolumn{2}{|c|}{17} & \multicolumn{2}{|c|}{18} & \multicolumn{2}{|c|}{19} \\
\hline Sex & M & $\mathrm{F}$ & M & $\mathrm{F}$ & M & $\mathrm{F}$ & M & $\mathrm{F}$ & M & $\mathrm{F}$ \\
\hline Nr. of Subj. & 9 & 6 & 18 & 8 & 13 & 12 & 10 & 6 & 9 & 6 \\
\hline$\dot{\mathrm{V}}_{\mathbb{E}}(l / \min , \mathrm{BTPS})$ & $\begin{array}{l}100.223 \\
(15.363)\end{array}$ & $\begin{array}{l}77.527 \\
(5.576)\end{array}$ & $\mid \begin{array}{l}102.250 \\
(15.949)\end{array}$ & $\begin{array}{l}70.748 \\
(3.395)\end{array}$ & $\begin{array}{l}106.413 \\
(21.537)\end{array}$ & $\begin{array}{c}74.888 \\
(13.030)\end{array}$ & $\begin{array}{l}111.099 \\
(16.384)\end{array}$ & $\begin{array}{l}72.569 \\
(8.042)\end{array}$ & $\begin{array}{l}110.609 \\
(17.395)\end{array}$ & $\begin{array}{c}69.605 \\
(16.963)\end{array}$ \\
\hline$\dot{\mathrm{V}}_{\mathrm{E}}(l / \mathrm{kg} / \mathrm{min}, \mathrm{BTPS})$ & $\begin{array}{c}1.914 \\
(0.272)\end{array}$ & $\begin{array}{c}1.454 \\
(0.088)\end{array}$ & $\begin{array}{c}1.894 \\
(0.280)\end{array}$ & $\begin{array}{c}1.346 \\
(0.150)\end{array}$ & $\begin{array}{l}1.925 \\
(0.311)\end{array}$ & $\begin{array}{c}1.419 \\
(0.231)\end{array}$ & $\begin{array}{c}1.926 \\
(0.398)\end{array}$ & $\begin{array}{l}1.448 \\
(0.693)\end{array}$ & $\begin{array}{c}1.922 \\
(0.290)\end{array}$ & $\begin{array}{c}1.325 \\
(0.241)\end{array}$ \\
\hline $\begin{array}{l}\dot{\mathrm{V}}_{\mathrm{O}_{2}} \max \\
(\mathrm{l} / \mathrm{min}, \mathrm{STPD})\end{array}$ & $\begin{array}{r}2,582 \\
(0.389) \\
\end{array}$ & $\begin{array}{c}1.899 \\
(0.147)\end{array}$ & $\begin{array}{c}2.590 \\
(0.395)\end{array}$ & $\begin{array}{c}1.839 \\
(0.202) \\
\end{array}$ & $\begin{array}{c}2.647 \\
(0.526) \\
\end{array}$ & $\begin{array}{c}1.786 \\
(0.291)\end{array}$ & $\begin{array}{c}2.793 \\
(0.329)\end{array}$ & $\begin{array}{c}1.818 \\
(0.258)\end{array}$ & $\begin{array}{c}2.740 \\
(0.446) \\
\end{array}$ & $\begin{array}{c}1.796 \\
(0.286)\end{array}$ \\
\hline $\begin{array}{l}\dot{\mathrm{V}}_{\mathrm{O}_{2}} \max \\
(\mathrm{ml} / \mathrm{kg} / \mathrm{min}, \mathrm{STPD})\end{array}$ & $\begin{array}{l}49.48 \\
(6.51)\end{array}$ & $\begin{array}{l}35.48 \\
(2.71)\end{array}$ & $\begin{array}{l}47.82 \\
(5.63)\end{array}$ & $\begin{array}{l}34.94 \\
(4.96)\end{array}$ & $\begin{array}{l}47.74 \\
(6.34)\end{array}$ & $\begin{array}{l}33.93 \\
(5.31)\end{array}$ & $\begin{array}{l}48.13 \\
(7.06)\end{array}$ & $\begin{array}{l}36.35 \\
(5.80)\end{array}$ & $\begin{array}{l}47.62 \\
(7.02)\end{array}$ & $\begin{array}{l}34.38 \\
(3.79)\end{array}$ \\
\hline $\begin{array}{l}\text { Oxygen removal } \\
\text { ('. }{ }_{\mathrm{O}_{2}} \text { max. ml, STPD } \\
\dot{\mathrm{V}}_{\mathrm{E}} 1, \mathrm{BTPS} \text { ) }\end{array}$ & $\begin{array}{l}25.92 \\
(1.72)\end{array}$ & $\begin{array}{l}24.39 \\
(1.66)\end{array}$ & $\begin{array}{l}25.45 \\
(2.51)\end{array}$ & $\begin{array}{l}26.01 \\
(2.83)\end{array}$ & $\begin{array}{l}24.75 \\
(3.46)\end{array}$ & $\begin{array}{l}24.14 \\
(3.70)\end{array}$ & $\begin{array}{l}25.48 \\
(3.74)\end{array}$ & $\begin{array}{l}25.08 \\
(2.37)\end{array}$ & $\begin{array}{l}24.94 \\
(3.09)\end{array}$ & $\begin{array}{l}26.35 \\
(3.53)\end{array}$ \\
\hline $\begin{array}{l}\text { Oxygen pulse } \\
\text { (ml/beat) }\end{array}$ & $\begin{array}{l}13.25 \\
(2.16)\end{array}$ & $\begin{array}{c}9.34 \\
(0.77)\end{array}$ & $\begin{array}{l}13.09 \\
(2.10)\end{array}$ & $\begin{array}{c}9.59 \\
(1.34)\end{array}$ & $\begin{array}{l}13.59 \\
(2.74)\end{array}$ & $\begin{array}{c}9.23 \\
(1.53)\end{array}$ & $\begin{array}{l}14.46 \\
(2.13)\end{array}$ & $\begin{array}{c}9.52 \\
(1.71)\end{array}$ & $\begin{array}{l}14.01 \\
(1.89)\end{array}$ & $\begin{array}{c}9.38 \\
(1.57)\end{array}$ \\
\hline $\begin{array}{l}\text { Heart rate } \\
\text { (beats } / \mathrm{min} \text { ) }\end{array}$ & $\begin{array}{c}195.8 \\
(9.9)\end{array}$ & $\begin{array}{r}201.1 \\
(5.0)\end{array}$ & $\begin{array}{r}198.1 \\
(8.9)\end{array}$ & $\begin{array}{l}192.5 \\
(10.0)\end{array}$ & $\begin{array}{l}195.2 \\
(7.8)\end{array}$ & $\begin{array}{r}194.7 \\
(7.9)\end{array}$ & $\begin{array}{r}194.0 \\
(9.1)\end{array}$ & $\begin{array}{r}192.0 \\
(8.8)\end{array}$ & $\begin{array}{l}194.8 \\
(10.9)\end{array}$ & $\begin{array}{r}191.8 \\
(8.2)\end{array}$ \\
\hline $\mathrm{RQ}$ & $\begin{array}{c}1.111 \\
(0.054)\end{array}$ & $\begin{array}{c}1.095 \\
(0.062)\end{array}$ & $\begin{array}{c}1.099 \\
(0.049)\end{array}$ & $\begin{array}{c}1.077 \\
(0.054)\end{array}$ & $\begin{array}{c}1.091 \\
(0.064)\end{array}$ & $\begin{array}{l}1.086 \\
(0.078)\end{array}$ & $\begin{array}{c}1.116 \\
(0.093)\end{array}$ & $\begin{array}{c}1.117 \\
(0.045)\end{array}$ & $\begin{array}{c}1.106 \\
(0.039)\end{array}$ & $\begin{array}{c}1.147 \\
(0.042)\end{array}$ \\
\hline $\mathrm{PWC}_{170}(\mathrm{kpm} / \mathrm{min})$ & $\begin{array}{l}794.6 \\
(245.6)\end{array}$ & $\begin{array}{l}559.5 \\
(96.6)\end{array}$ & $\begin{array}{l}788.9 \\
(125.2)\end{array}$ & $\begin{array}{l}617.7 \\
(96.5)\end{array}$ & $\begin{array}{c}803.3 \\
(161.6)\end{array}$ & $\begin{array}{c}548.8 \\
(103.5)\end{array}$ & $\begin{array}{c}910.3 \\
(197.4)\end{array}$ & $\begin{array}{c}570.5 \\
(170.0)\end{array}$ & $\begin{array}{c}847.9 \\
(128.6)\end{array}$ & $\begin{array}{c}556.8 \\
(109.3)\end{array}$ \\
\hline $\begin{array}{l}\mathrm{PWC}_{170} \\
(\mathrm{kpm} / \mathrm{kg} / \mathrm{min})\end{array}$ & $\begin{array}{l}15.12 \\
(4.25)\end{array}$ & $\begin{array}{l}10.48 \\
(1.60)\end{array}$ & $\begin{array}{l}14.58 \\
(1.99)\end{array}$ & $\begin{array}{l}11.70 \\
(1.95)\end{array}$ & $\begin{array}{l}14.59 \\
(2.67)\end{array}$ & $\begin{array}{l}10.36 \\
(1.45)\end{array}$ & $\begin{array}{l}15.71 \\
(4.02)\end{array}$ & $\begin{array}{l}11.51 \\
(3.56)\end{array}$ & $\begin{array}{l}14.77 \\
(2.59)\end{array}$ & $\begin{array}{l}10.63 \\
(1.36)\end{array}$ \\
\hline
\end{tabular}

全体的には顸ばい状態にあった。また性差につい ては72〜75完であった

見在，Physical resources の站埸加ら持久走の 背景にある有酸素的作栄能を最も客観的に，しか も国際的にも広く用いら倍赖されている指慓之

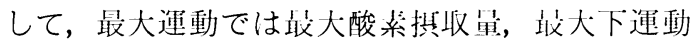
では $\mathrm{PWC}_{170}$ がある。これまで，わが四において あ日本人一般青少年を対象として多くの楩況が年 令的推移あるいは性差という峴点から淪じられて

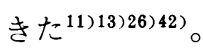

有酸素的作業能の年分的推栘を，まず $\dot{\mathrm{V}} \mathrm{o}_{2} \mathrm{max}$ $(l / \mathrm{min})$ についてみると，猪飼(9)10)，男子は 12 ～13才頃から急激な発達がみられ，17才まで增加 し，その後は同一水準を保ち25才を過ぎる頃から わずかに低下する。父子では15才まで直線的に增 加を示すが，その後は横ばい状態になるとしてい
る。また包井ら ${ }^{15)}$ は，罗于は年分の增加と共に漸 次增加し13才から16才にいたる発省促進则では䭪 著な增加がみられ，17１8才でその敂问水準に達 する。文于は全体として打ずかから年次的增加 の傾向がみら机るとしている。さらに北川ら ${ }^{17)}$ は,

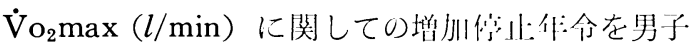
は17. 5才，女子は15才と報告している。

$\dot{\mathrm{V}}_{2} \max (\mathrm{ml} / \mathrm{kg} / \mathrm{min})$ につては, 化非ら ${ }^{15)}$ 男子ではやや山凸をくり返しながらも伞体的倾们 としては，年令が進むにしたがって大きくなり， 文厅は12才から16才までは減少し，17，18才でや や增大し12才の水準に庆ると報告している。猪飤 10)は 9 才〜15才まではほぼ定常状態を保ち。それ 以後は20才まで值は低下していき20才からは一定 水售になる。他う，文了は16才までは年分にとも ない值は低下していくが，それ以後はほ涪横ばい 
状態になるととを述べている。

次に $\mathrm{PWC}_{170}(\mathrm{kpm} / \mathrm{min})$ についてみると, 石河 13)は男子では 12 才〜 15 才にかけて漸增傾向がみ られ，文子ではこの增加が 14 才で終わる。また $\mathrm{PWC}_{170}(\mathrm{kpm} / \mathrm{kg} / \mathrm{min})$ の值は, 男子では 14 才ま で増加して以後減少するが, 女子ではての漸減傾 向が男子より早く 12 才より始まっていると述べて いる。

そこで，夜間高校定時制生徒の有酸素的作業能 の年令的推移を先に述べた研究結果と比較しなが らみると，男子の場合， $\dot{\mathrm{V}} \mathrm{o}_{2} \max (l / \mathrm{min})$ は 15 才 から18才までわずかではあるが増加を示し，19才 で横ばい状態になるというように，猪飼910)，龟 井ら ${ }^{15)}$, 北川ら ${ }^{17)}$ とほぼ一致した結果が得られた。

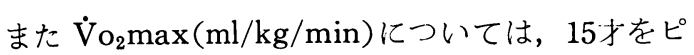
一クとしてその後わずかではあるが減少の傾向を 示すというように，龟井ら ${ }^{15)}$ の報告とは一致しな かったが，猪飼 ${ }^{910)}$ の年令的推移に近い值が得ら れた。

一j, 女子の $\dot{\mathrm{V}} \mathrm{o}_{2} \max (l / \mathrm{min})$ は15才から19才 まで $1.7 \sim 1.8 \mathrm{l} / \mathrm{min}, \dot{\mathrm{V}} \mathrm{o}_{2} \max (\mathrm{ml} / \mathrm{kg} / \mathrm{min})$ では 18才でわずかに高い值を得たが，全体としては34 〜 $36 \mathrm{ml} / \mathrm{kg} / \mathrm{min}$ と, 両者とあわずかの凹凸はあ るが横ばい状態を示し，猪飼 ${ }^{9) 10)}$ の絬果に近い年 令的推移がみられた。

$\mathrm{PWC}_{170}(\mathrm{kpm} / \mathrm{min})$ についてみると，男子の場 合，18才までわずかの増加を示し，19才で減少 し，女子は16才で最も高い值を示したが，全体的

Table 3 Differnces in physique, skinfold thickness, and aerobic work capacity of the night part-time and the full-time high school students

\begin{tabular}{|c|c|c|c|c|c|c|c|c|}
\hline \multirow{2}{*}{\multicolumn{2}{|c|}{$\frac{\text { Sex }}{\text { Age }(\text { years })}$}} & & \multicolumn{3}{|c|}{ Male } & \multicolumn{3}{|c|}{ Female } \\
\hline & & & 15 & 16 & 17 & 15 & 16 & 17 \\
\hline \multirow{2}{*}{\multicolumn{2}{|c|}{$\begin{array}{l}\text { Number of } \\
\text { subjccts }\end{array}$}} & & 9 & 18 & 12 & 6 & 8 & 12 \\
\hline & & & 30 & 30 & 30 & 30 & 30 & 30 \\
\hline \multirow{2}{*}{\multicolumn{2}{|c|}{$\begin{array}{l}\text { Body } \\
\text { height }(\mathrm{cm})\end{array}$}} & $\mathrm{P} . \mathrm{T}$ & *159. 20(4.87) & $*_{162.88(4.50)}$ & $165.93(6.33)$ & $153.81(4.02)$ & $155.30(4.55)$ & $*: 152.37(3.59)$ \\
\hline & & $\mathrm{F} . \mathrm{T}$ & $165.23(6.49)$ & $166.03(5.30)$ & $167.92(4.47)$ & $154.80(5.64)$ & $154.48(4.19)$ & $157.31(4.54)$ \\
\hline \multirow{2}{*}{\multicolumn{2}{|c|}{$\begin{array}{l}\text { Body } \\
\text { weight }(\mathrm{kg})\end{array}$}} & P.T & $52.48(5.49)$ & $54.21(6.04)$ & ${ }^{*} 55.25(6.87)$ & $53.28(2.49)$ & $53.06(5.65)$ & $52.88(5.39)$ \\
\hline & & F. T & $55.77(9.52)$ & $57.58(6.31)$ & $61.22(6.93)$ & $50.19(5.86)$ & $51.59(4.72)$ & $55.03(6.82)$ \\
\hline \multirow{8}{*}{ 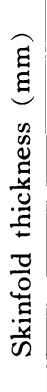 } & \multirow{2}{*}{$\begin{array}{l}\text { Upper } \\
\text { arm }\end{array}$} & $\mathrm{P} . \mathrm{T}$ & $10.56(3.47)$ & $9.13(4.48)$ & $* * 6.74(2.31)$ & $17.63(2.70)$ & $19.46(5.19)$ & $18.73(6.16)$ \\
\hline & & $\mathrm{F} \cdot \mathrm{T}$ & $10.24(4.73)$ & $7.72(3.38)$ & $12.01(4.66)$ & $16.40(4.82)$ & $17.62(4.47)$ & $17.99(5.79)$ \\
\hline & \multirow{2}{*}{ Scapula } & $\mathrm{P} . \mathrm{T}$ & $10.40(2.97)$ & $9.73(3.78)$ & $8.92(2.41)$ & $16.71(2.13)$ & $19.36(6.23)$ & $18.86(5.35)$ \\
\hline & & $\mathrm{F} . \mathrm{T}$ & $9.59(5.63)$ & $9.20(3.32)$ & $11.46(4.67)$ & $14.73(4.80)$ & $15.97(4.66)$ & $18.04(6.68)$ \\
\hline & \multirow{2}{*}{ Waist } & $\mathrm{P} . \mathrm{T}$ & $14.65(8.13)$ & $9.95(5.98)$ & $*_{10.12(3.32)}$ & $*_{21.68(4.88)}$ & $*_{21.85}(5.00)$ & $* 22.25(7.16)$ \\
\hline & & $\mathrm{F} . \mathrm{T}$ & $12.55(7.71)$ & $12.22(7.51)$ & $15.50(8.04)$ & $15.71(5.73)$ & $16.63(5.91)$ & $16.28(6.51)$ \\
\hline & \multirow{2}{*}{$\begin{array}{l}\text { Umbil- } \\
\text { icus }\end{array}$} & $\mathrm{P} . \mathrm{T}$ & $11.42(4.15)$ & $10.36(8.05)$ & $* * 7.88(3.06)$ & $19.20(5.52)$ & $16.73(4.64)$ & $21.75(6.84)$ \\
\hline & & $\mathrm{F} . \mathrm{T}$ & $12.76(7.40)$ & $11.84(5.78)$ & $15.34(7.17)$ & $17.04(5.43)$ & $17.67(5.19)$ & $17.80(6.46)$ \\
\hline \multirow{2}{*}{\multicolumn{2}{|c|}{$\begin{array}{l}\dot{\mathrm{V}}_{\mathrm{o}_{2}} \max \left({ }^{\prime} /\right. \\
\min , \mathrm{STPD})\end{array}$}} & P.T & $2.58(0.38)$ & $*_{2.59}(0.39)$ & $* * 2.64(0.52)$ & $* * 1.89(0.14)$ & $1.83(0.20)$ & $1.78(0.29)$ \\
\hline & & $\mathrm{F} . \mathrm{T}$ & $2.74(0.36)$ & $2.87(0.40)$ & $3.07(0.34)$ & $1.77(0.42)$ & $1.83(0.29)$ & $1.82(0.30)$ \\
\hline \multirow{2}{*}{\multicolumn{2}{|c|}{$\begin{array}{l}\dot{\mathrm{V}} \mathrm{O}_{2} \max (\mathrm{ml} \\
/ \mathrm{kg} / \mathrm{min}, \\
\text { STPD })\end{array}$}} & P. T & $49.48(6.51)$ & $47.82(5.63)$ & $47.74(6.34)$ & $35.48(2.71)$ & $34.94(4.96)$ & $33.93(5.31)$ \\
\hline & & F. T & $49.65(6.36)$ & $50.35(7.97)$ & $50.40(5.10)$ & $35.17(6.98)$ & $35.68(5.89)$ & $33.18(5.97)$ \\
\hline \multirow{2}{*}{\multicolumn{2}{|c|}{$\begin{array}{l}\mathrm{PWC}_{170} \\
(\mathrm{kpm} / \mathrm{min})\end{array}$}} & $\mathrm{P} . \mathrm{T}$ & $794.61(2$ & $788.91(125.29)$ & $803.32(161.66)$ & $559.50(96.60)$ & $617.70(96.55)$ & $548.88(103.59)$ \\
\hline & & $\mathrm{F} . \mathrm{T}$ & $904.15(138.42)$ & $965.78(189.67)$ & $978.27(168.75)$ & $562.75(137.95)$ & $593.68(87.90)$ & $614.65(120.95)$ \\
\hline \multirow{2}{*}{\multicolumn{2}{|c|}{$\begin{array}{l}\mathrm{PWC}_{170} \\
(\mathrm{kpm} / \mathrm{kg} / \\
\mathrm{min})\end{array}$}} & $\mathrm{P} . \mathrm{T}$ & $15.12(4.25)$ & $* * 14.58(1.99)$ & $14.59(2.67)$ & $10.48(1.60)$ & $11.70(1.95)$ & $10.36(1.45)$ \\
\hline & & $\mathrm{F} . \mathrm{T}$ & $16.54(3.28)$ & $16.79(2.98)$ & $16.02(2.46)$ & $11.13(2.40)$ & $11.54(1.58)$ & $11.22(2.16)$ \\
\hline
\end{tabular}

P.T : Part-Time F.T : Full-Time $* \mathrm{P}<.05 * * \mathrm{P}<.01 \quad$ Means $(\mathrm{Sd})$ 


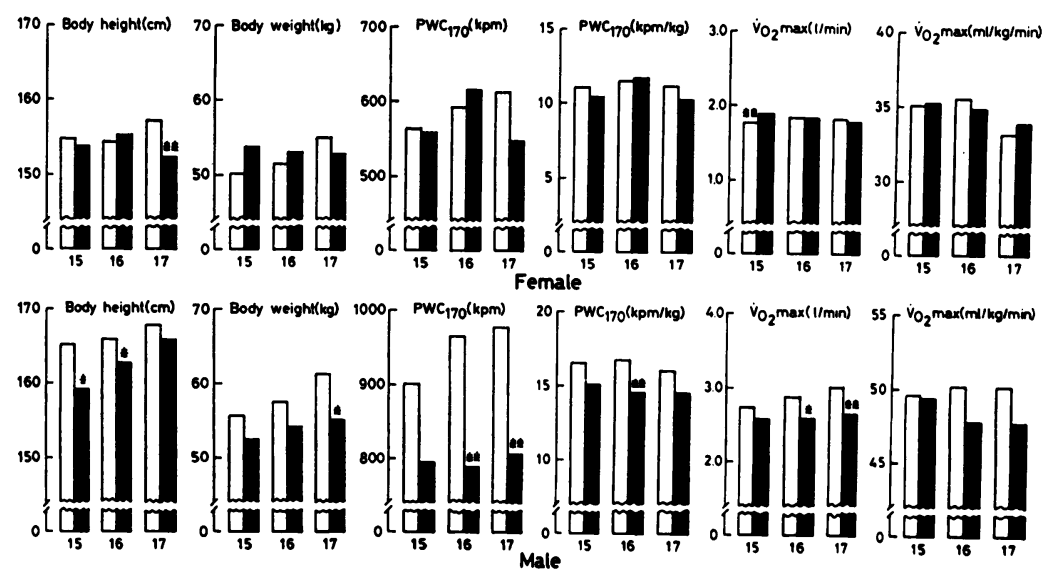

Shaded : night part-time, $\quad * \mathrm{P}<.05, \quad * * \mathrm{P}<.01$

Fig. 1 Differences in physique and aerobic work capacity of the night part-time and the full-time high school students

には 550 〜 $600 \mathrm{kpm} / \mathrm{min}$ とほぼ一定水準を保って

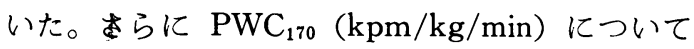
は, 15 才から 19 才まで男子は $14 \sim 15 \mathrm{kpm} / \mathrm{kg} /$ min，女子は $10 \sim 11 \mathrm{kpm} / \mathrm{kg} / \mathrm{min}$ とほぼ一定の 水準にあった。これらの結果は石河 ${ }^{13)} の$ 年令的推 移と一致しなかったが，乙の点についてはこれま でわが国の一般青少年を対象とした $\mathrm{PWC}_{170}$ の研 究は多数あるにあかかわらず $\mathrm{PWC}_{170}$ の年令的推 移をみた研究が少な(いので13)43)44)，今後さらに検 討を加えていかなければならないと思われる。

2. 夜間高校定時制生徒之全日制生徒の有酸素 的作業能の比較について

本研究の測定対象となった被検者は商業市街地 と農村部の両者から通学している生徒から構成さ れている。でれらの夜間高校定時制生徒と比較検 討するための全日制の資料としては，同じ栃木県 下で同様の測定方法で得た吉沢 ${ }^{41)}$ の資料を用い た。吉沢は都市と農村青少年を別々に求めてある ので，それらの值を原罂よりあらためて計算しな おし, 都市之農村青少年を合計し, 形態, 皮脂片 及び有酸素的作業能の平均值, 標準偏差を求め た。なお第 3 表はこのようにして求めた全日制生 徒の值之, 本研究で得た夜間高校定時制生徒の值 とを15，16，17才について比較したものであり， 第 1 図はそのなかで形態, 有酸素的作業能を図示 したあのである。

$\mathrm{PWC}_{170}(\mathrm{kpm} / \mathrm{min})$ については，男子において すべての年令で全日制生徒が大きく夜間高校定侍
制生徒を上回り，とくに16才，17才では有意差が 認められた。一方，女子では15才，17才で全目制 生徒が上回り，16才では反対に夜間高校定時制生 徒が上回るという結果を示したが，いずれも有意 差は認められなかった。

$\dot{\mathrm{V}}_{2} \max (\mathrm{l} / \mathrm{min})$ においては, 男子の場合, す べての年令で全日制生徒が上回り，16才，17才で 有意差が認められるという $\mathrm{PWC}_{170}(\mathrm{kpm} / \mathrm{min})$ と 同じ結果を示したのに対し，女子では15才で夜間 高校定時制生徒が有意着をもって上回り，16才，

17才では全く差がみられなかった。

$\mathrm{PWC}_{170}(\mathrm{kpm} / \mathrm{kg} / \mathrm{min})$ では, 男子が $\mathrm{PWC}_{170}$ $(\mathrm{kpm} / \mathrm{min})$ 同栐，すべての年令で全日制生徒が 上回り，とくに16才では有意差をむって上回っ ていた。それに対して，女子をみると， $\mathrm{PWC}_{170}$ $(\mathrm{kpm} / \mathrm{min})$ と同じような傾向を示しいずれも有 意差はみられなかった。

$\dot{\mathrm{V}}_{\mathrm{o}_{2}} \max (\mathrm{ml} / \mathrm{kg} / \mathrm{min})$ では, 男子がすべての年 令で有意差はみられなかったが, 全日制生徒が上 回り，他方，女子では15才，17才でわずかに依間 高校定時制生徒が，16才では反対に全日制生徒が 上回っていた。

このように液間高校定時制生徒，全日制生徒と 同じ测定方法で得られた資料を比較したわけであ るが, 男子においては絶対值, 単位体重当たりと む全日制生徒がすべての年令において明らかに上 回っていた。一少，女子の比較をみると, 絶対值, 単位体重当たりとむ，各年令においてわずかの大 
小は認められるが，全体的にみると夜間高校定時 制生徒と全日制生徒との間には男子ほどの差はみ られなかった。

$\mathrm{PWC}_{170}(\mathrm{kpm} / \mathrm{min}), \dot{\mathrm{V}}_{o_{2}} \max (l / \mathrm{min})$ のような 絶対值は形態との相関が高いといわれている10)15) 17)31,35)。第 3 表, 第 1 四上り液間高校定時制生徒 と全日制生徒との形態をみると, 男子の場合, 身 長，体重とあすべての年令で全日制生徒が上回っ ている。それに対して女子は, 全日制生徒が上回 っていたのは15才，17才の身長，17才の体重と男 子ほどのはっきりした形態の差はみられなかっ た。したがって, 絶対值では形態的な特徵が男子 では大きな差となってあらわれ，また女子では男 子ほどの形態の影響をうけなかったものと思われ る。

しかし，とのような形態の影響，とくに体重と の関係を考虑して単位体重当たりの $\mathrm{PWC}_{170}, \dot{\mathrm{Vo}}_{2}$ $\max$ に換算しても, 男子では全日制生徒が明らか に上回わり，また女子においては，やはり絶対值 と同じように男子ほどのはっきりした差がみられ なかったというととは, 测定方法が全く同じであ
ったととを考えると，さらに，てれらのとくに男 子における差は何に起因するのかを, トレーニン グの問題, 栄敛の問題, 生活時間構造の問題など を含めて考えていかなければならない。

第 4 表は本研究の测定対象となった被検者に対 して1日の生活時間調査を，千葉4)の調査法に準 じて行ない, 同年代の同地域の全日制生徒と比較 したものである。なお対照としての全日制生徒は 併設の杤木県立氏家高校学校の全日制生徒のなか から無作為に 2 学級を抽出したものである。この 第 4 表からも明らかなように 1 日のなかで夜間高 校定時制生徒は全日制と比較して, 休息時間, レ クリェーション時間はもちろん, 身体活動に要す る時間が極めて少ない。乙れについては増田ら ${ }^{25)}$, 石河 ${ }^{14)}$, 勤労青少年の体力の問題として トレーニングする時間が非常に少ないことをあげ ている。他方，藤本ら ${ }^{6)}$ は依間高校定時制生徒は 摄取食物が少ないてとを述べている。

てのようなととを考えあ打せると，有酸素的作 業能の最む客観的な指槽である $\mathrm{PWC}_{170}(\mathrm{kpm} / \mathrm{kg}$ $/ \mathrm{min}), \quad \dot{\mathrm{V}}_{2} \max (\mathrm{ml} / \mathrm{kg} / \mathrm{min})$ において ${ }^{1) 8}$, 男子

Table 4 Comparison of life time between the night part-time high school students and the full-time high school students

\begin{tabular}{|c|c|c|c|c|c|c|c|c|}
\hline & \multicolumn{4}{|c|}{ Male } & \multicolumn{4}{|c|}{ Female } \\
\hline & \multirow{2}{*}{\multicolumn{2}{|c|}{$\begin{array}{l}\text { night part-time high } \\
\text { school } \\
\qquad n=55\end{array}$}} & \multirow{2}{*}{\multicolumn{2}{|c|}{$\begin{array}{l}\text { full-time high school } \\
\qquad \mathrm{n}=50\end{array}$}} & \multirow{2}{*}{\multicolumn{2}{|c|}{$\begin{array}{l}\text { night part-time high } \\
\text { school } \\
\qquad n=39\end{array}$}} & \multirow{2}{*}{\multicolumn{2}{|c|}{$\begin{array}{l}\text { full-time high school } \\
\qquad n=68\end{array}$}} \\
\hline & & & & & & & & \\
\hline & minute & percentage & minute & percentage & minute & percentage & minute & percentage \\
\hline sleeping hours & 441 & 30.6 & 434 & 30.1 & 423 & 29.3 & 431 & 29.9 \\
\hline meal & 66 & 4.5 & 89 & 6.1 & 60 & 4.1 & 81 & 5.6 \\
\hline $\begin{array}{l}\text { dressing, bathing, } \\
\text { washing }\end{array}$ & 45 & 3.1 & 59 & 4.0 & 54 & 3.7 & 55 & 3.8 \\
\hline family affairs & 3 & 0.2 & 7 & 0.4 & 26 & 1.8 & 51 & 3.5 \\
\hline recreation & 41 & 2.8 & 112 & 7.7 & 39 & 2.7 & 105 & 7.2 \\
\hline $\begin{array}{l}\text { going to school, } \\
\text { going to office }\end{array}$ & 62 & 4.3 & 68 & 4.7 & 54 & 3.7 & 77 & 5.3 \\
\hline working hours & 449 & 31.1 & 0 & 0 & 448 & 31.1 & 0 & 0 \\
\hline rest in office & 64 & 4.4 & 0 & 0 & 65 & 4.5 & 0 & 0 \\
\hline lessons in day time & 0 & 0 & 360 & 25.0 & 0 & 0 & 360 & 25.0 \\
\hline $\begin{array}{l}\text { lessons in night } \\
\text { time, hobby }\end{array}$ & 180 & 12.5 & 0 & 0 & 180 & 12.5 & 10 & 0.6 \\
\hline study in home & 24 & 1.6 & 179 & 12.4 & 32 & 2.2 & 158 & 10.9 \\
\hline club activities & 33 & 2.2 & 64 & 4.4 & 26 & 1.8 & 67 & 4.6 \\
\hline rest time & 32 & 2.2 & 68 & 4.7 & 33 & 2.2 & 45 & 3.1 \\
\hline
\end{tabular}


は液間高校定時制生徒が全日制生徒より明らかに 劣っていることとしては，乙うした身休活動時間 の不足, さらには栄篒椇取量の不赴なども大きく 影箱しているものと考えられる。他元，文子にお いては男子ほどすべての倍令においてはっきりし た善はみられなかったわけであるが，スポーッテ ストの持久术では大きな差があったにもかかわら ず，てれらの単位体重当たりの $\mathrm{PWC}_{170}, \dot{\mathrm{V}} \mathrm{o}_{2} \max$ ではっきりした差が出なかったというととは，疲 労という因子を除けば差がなくなるのか，あるい はこれまでの持久走の测定の際に男子より一層疲 労した状態で測定に望んだため，十分な意欲をも って測定に参加していなかったのかというととに 関しては今後さらに詳紼に検討していく必要があ る。

これまでの伩閪高校定時制生:徒と全日制生徒の スポーツテストのなかで持人走を比挍してみると 全日制生徒が大きく上问っている。しかし，伩間 高校定将制生:徒は 1 日の労働が終わり登校の時点 で大半の生徒が唛学した状態にあるいうこと

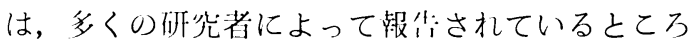
であもる (4)5717)23)。したがって今後，伩間高校定

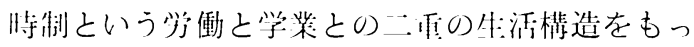
ている特殊な特:徒について测定をする埸合には， 岥労の因子を除いた状態で行なうという配虑がと くに重要であると思打机る

\section{要約}

15 19才の枋术県内の依閒高校定時制生徒，男 于59名, 女子 38 名, 計 97 名について, 白転車エル ゴメーターにより $\mathrm{PWC}_{170}$ 及び $\dot{\mathrm{V}} \mathrm{o}_{2} \max$ を疲労 していない状態時に测定し，同時に全日制生徒と の比較をし次のような結果を得た。

1) $\mathrm{PWC}_{170}(\mathrm{kpm} / \mathrm{min})$ については, 男于が 18 才で $910 \mathrm{kpm} / \mathrm{min}$ と敦も高い值を示し，その他の 脌令では約 $800 \mathrm{kpm} / \mathrm{min}$ であった。女子はすべ てい年价で約 $600 \mathrm{kpm} / \mathrm{min}$ であった。 $\mathrm{PWC}_{170}$ $(\mathrm{kpm} / \mathrm{kg} / \mathrm{min})$ では 15 19才まで男子が 14〜15 $\mathrm{kpm} / \mathrm{kg} / \mathrm{min}$, 六子が $10 \sim 11 \mathrm{kpm} / \mathrm{kg} / \mathrm{min}$ とほ ぼ一定水準にあった。

2) $\dot{\mathrm{V}} \mathrm{o}_{2} \max (l / \mathrm{min})$ においては, 男千では 15 〜18才までわずかの增加がみられたが，从子标标 いてはす心゙ての年令で約 $1.8 \mathrm{l} / \mathrm{min}$ とほとんど一。
定の水準にあった。 $\dot{V}_{o_{2}} \max (\mathrm{ml} / \mathrm{kg} / \mathrm{min})$ をみる と, 男子が15才で $49.48 \mathrm{ml} / \mathrm{kg} / \mathrm{min}$ と最も高い 值をホし，そ机以降はわずかではあるが咸少して いた。从子は18才で $36.35 \mathrm{ml} / \mathrm{kg} / \mathrm{min}$ と最も高い 值を示し，その他の年令では $34 \sim 35 \mathrm{ml} / \mathrm{kg} / \mathrm{min}$ の籁囲にあった。

3）性养についてみると, $\mathrm{PWC}_{170}(\mathrm{kpm} / \mathrm{min})$

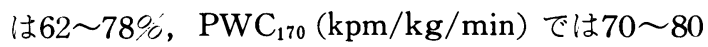
$\%, \dot{\mathrm{V}_{2}} \max (l / \mathrm{min})$ では 65〜 73\%， そして $\mathrm{Vo}_{2}$ $\max (\mathrm{ml} / \mathrm{kg} / \mathrm{min})$ では 72 75\%であった。

4）15才，16才，17才について，夜間高校定時 制生徒と全日制生:徒を比較してみると, $\mathrm{PWC}_{170}$ $(\mathrm{kpm} / \mathrm{min})$ 及び $\dot{V} o_{2} \max (l / \mathrm{min})$ では, 男子がす べての年令で全日制生徒が大きく上回り, とくに 16才，17才では有意恙が認められたが，从子では $\mathrm{PWC}_{170}(\mathrm{kpm} / \mathrm{min})$ に扔いてはすべての年令で有 意差はみられず，また $\dot{V}_{o_{2}} \max (l / \mathrm{min})$ も15才で 依開高校定時制生徒が有意差をもってト.㺫ってい たが，16才，17才ではほとんど保がなった。 $\mathrm{PWC}_{170}(\mathrm{kpm} / \mathrm{kg} / \mathrm{min}), \dot{\mathrm{V}}_{2} \max (\mathrm{ml} / \mathrm{kg} / \mathrm{min})$

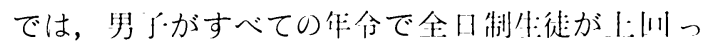
ていたけ机よ゙も，16才の $\mathrm{PWC}_{170}(\mathrm{kpm} / \mathrm{kg} / \mathrm{min})$

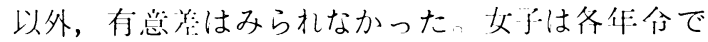

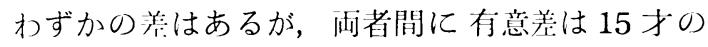
$\dot{\mathrm{V}} \mathrm{O}_{2} \max (l / \mathrm{min})$ 以外垫められなかった。

(受付胎利 51 年 7 月 24 日)

\section{参考文献}

1) Andersen, A.L. (1961) : Physical working capacity. Health and Fitness in the world. The Atheletic Institute., 365-367.

2) Balke, B. and Ware, R.W. (1959) : An experimental study of physical fitness of Air Force personnel. U.S. Armed. Forces. Med. J., 10, 675-689.

3) Binkhorst, R.A. (1963) : A rapid method for the determination of aerobic capacity. Arbeitsphysiol., 19. 459-467.

4）下㻉裕典(1958)：定時制高等学校生徒の生活之 健冰汇関する研究。第 1 編, 生活構造, 民族衛 24(3), 99-111.

5) 千葉裕典(1958)：定時制高等学校生徒の生活之 健康汇関する研究. 第 2 編, 健康状態. 民族衛 1.: 24(3), 112-128. 
6）藤本 守, 渡辺義行, 高橋幾代, 由村它弘 (1970)：夜間定時制高校生の体力について。体 去学: 研究 13(1), 17-25.

7）井留延大(1971)：定時制临徒の始業時における 投労について。保健の科兴: 13，474-478.

8）猪飼近夫(1966）：业吸萿環機能からみた体力の 限界. 呼吸之循環 16,449-456.

9）猪飼道夫(1967)：青少年最大作業能の比較民族 学的研究. 日本生理誌 $29,517-522$.

10）猪飼道夫(1970)：日本の作業能力及び生長諸段 階における適応能の砳究. JIBP/HA Working Capacity 研究班, 1-21.

11) Ikai, M. (1970) : Aerobic work capacity of Japanese people. Res. J. Phys. Ed., 14(3), 137-142.

12）稲葉ナミ，大村彰子，佐藤緋佐子(1966)：披労 調査（第 1 報）高校生について。家政学雑誌 17(2), 56-60.

13）石河利宽(1968)：自転車エルゴメーターによる Ergometry に関する研究. 口本体有協会スポ 一ツ科学歪监公, 1-6.

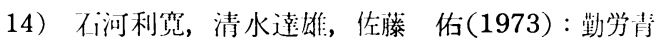

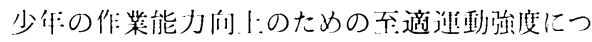
いて, 体南科兴: 1, 73-80.

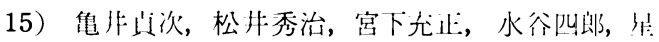
川 保，监皇進太蚛(1972)：青少年にみら机る 最大酸素椇取量と体重との関係. 体力科兴: 21 , 136-142.

16）加藤延雄(1970)：高校生の体力尖態調査につい ての一考察. 体育学:研究 14(5), 275.

17）北川 薰, 猪飼道夫(1972)：青少年期における 最大酸素椇取量と形態との関連性. 体育学研究 17 (3), 159-166.

18）近藤 敬, 水野良和, 奥野正良 (1960)：定時制 高校の体力医学的検討. 三重医学 4(2),287289.

19）小谷新太郎, 千葉裕典, 内田利一· (1964) : 定時 制高等学校生徒の健逮に関する考察。日本公衛 志 11(3), 171-185.

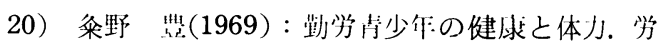
働衛作: 10(6), 10-15.

21) Lester, M., Sheffield, L.T., Trammel, P. and Reeves, J.J. (1968): The effect of age and athletic training on the maximal heart rate during muscular exercise. American Heart. J., 76(3), 370-376.
22) Macnab, R.B.J., Conger, P.R. and Taylor, P.S. (1969): Differences in maximal and submaximal work capacity in men and women. J. Appl. Physiol., 27, 644-648.

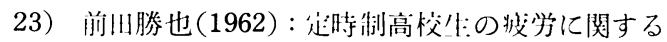
研究 (2). 体青学研究 17(1), 138.

24）堌田 尤，成末回天倠(1971）：勤労青少估の体 力の問題点. 体力研究 $21,937-948$.

25）増田 允, 芝山秀太郎, 汇懆 博, 内野欽间 (1972)：勤労青少年の体力と生活時間構造. 保 健の科学: 14, 629-633.

26) Matsui, H. (1972) : Maximum oxygen intake and its relationships to body weight of Japanese adolescents. Medicinc and Science in Sports, 4(1), 29-32.

27）文部省体育局：体力遇動能力調查報告聿（昭和 43年一昭和 49 年)

28）元 和坠，飯田穎男，人越裕美(1967)：高等学 枍定時制課程における体力についての一考察. 体青学研究 11(5), 60 .

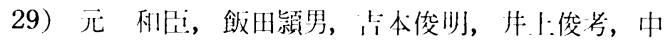

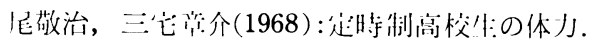

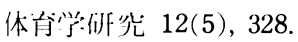

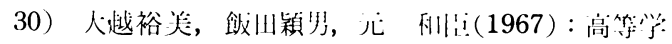

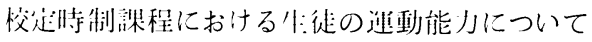
の一考察. 体青学诃觉 11(5), 60 .

31) Saltin, B. (1967) : Maximal oxygen uptake in athletes. J. Appl. Physiol., 23(3), 353-358.

32）鈴木継关，广次澄关子，鈴小久乃，千葉裕典 （1954）：定時制高等学校生徒の食事に関する考 察, その 1. 食事内容について, 日本公衛誌 9, 464-468.

33）高橋英次, 加藤勝雄, 阿部十郎, 川上吉昭, 矢 野毫夫(1958)：青年期における高血压的傾向に 関する研究, 第 1 報 勤労学徒との血圧水準及 びその体格，性格との関係。民族衛生２4(5)， 263-277.

34）高橋英次, 加藤勝婎, 川上占昭, 阿部十郎, 不 黒弘之，金山昭治(1959）：青年期における高血 压的傾们に関する研劣，第 2 韩 夜閒高校生の 高血压的傾们とビタミン剂投与武験成績，民族 街住: 25(3), 384-392.

35) Taylor, H.L., Buskirk, E. and Henschel, A. (1955) : Maximal oxygen intake an objective measure of the cardio-respiratory performance. J. Appl. Physiol., 8, 73-80. 
36）杤木県教育委員会：本県児童生徒の体力（昭和 41 年一昭和 50 年.)

37）我妻由規(1969)：体㕕之夜間生:の波労. 体青の 科学 18(9), 566-569.

38）我妻由規(1967)：体肖之液間生の疲労. 体命の 科学 18(8), 466-468.

39) Weiner, J.S.(1969) : Human Biology. A guide to field method. IBP Handbook No.9., Blackwell Scientitfc Publications, Oxford.

40) Wilmore, J.H.(1967) : Physical work capacity of young girls, 7-13 years of age. J. Appl. Physiol., 22, 923-928.
41）占沢茂弘(1972)：都市と農村青少年の有酸素的 作業能に関する研究. 体力科学 21, 161-175.

42）吉沢茂弘(1971)：農村青少年の作業能に関する 研究(I ). 体育学研究 15(3), 21-32.

43）吉沢茂弘(1971)：生態学的にみた都市と農村青 少年の有酸絭的作業能に関する研究. 体力科学: $20,125-133$.

44）吉沢茂弘, 石崎忠利, 石浜松子, 室井和比古, 杉山光子(1972)：地域環境からみた青少年の有 酸素的作業能に関する研究. 体肖の科学 22 (10), 675-680. 